https://doi.org/10.15407/scine16.04.034

FOROSTYANA, N., MYKHAILOVA, H., OSIIEVSKA, V., and MARCHUK, N.

Kyiv National University of Trade and Economics, 19, Kyoto St., Kyiv, 02156, Ukraine,

+380 44513 8172, ktms@knute.edu.ua

\title{
STUDY OF THERMAL CONDUCTIVITY CHARACTER OF NATURAL AND CHEMICAL TEXTILE FILLERS FOR BLANKET PRODUCTION
}

Introduction. The significant role in optimization of assortment and designing of blankets with given properties belongs to the choice of the filler, in particular to its thermophysical parameters, which differ in different materials.

Problems. Thermal conductivity of blankets with fillers of protein origin in particular sheep's wool, camel wool, cashmere wool has not studied enough. Control and measurement of the specified indicator will optimize the choice of materials during the design of bedding products with volumetric fillers, specifically blankets.

Purpose. Estimation of thermal conductivity of different types fillers.

Materials and Methods. Samples of fillers of different fiber composition (sheep's wool, camel wool, cashmere wool) were the objects of the study. Experimental researches were carried out in Kyiv National University of Trade and Economics laboratories using the module "Heat" of the multi-functional measuring module device $M I G-1.3$. The photos of the fillers were made using universal measuring computer with resolution of 600 pixels.

Results. Microscopic studies of the fibers have shown that the density of the fillers is different, and the mass of air in them and, accordingly, the mass of the filler fibers themselves differ, that in a result affect the thermal conductivity of the material. According to the obtained data, a number of fillers were formed according to their thermal conductivity: camel wool $\rightarrow$ sheep wool $\rightarrow$ cashmere wool $\rightarrow$ polyester fiber.

Conclusions. The results showed that the most effective in terms of heat saving is a filler made of camel wool, while polyester fiber has a thermal conductivity in 2.2 times lower. It should be taken into account forming the heatprotective properties of bedding with bulky fillers, including blankets, with the aim of optimization of their range.

Keywords: blanket, sheep's wool, camel wool, cashmere wool, polyester fiber, and thermal conductivity.

The human body is a self-regulating system with an internal heat source, in which under normal conditions, the amount of heat produced corresponds to the amount of heat transferred to external environment. The heat balance between the human body and the environment ensures the conditions of comfort [1]. If the body's heat production is equal to the heat transfer, then the human body temperature remains constant. L:ke in the case of

Citation: Forostyana, N., Mykhailova, H., Osiievska, V., and Marchuk, N. Study of Thermal Conductivity Character of Natural and Chemical Textile Fillers for Blanket Production. Sci. innov. 2020. V. 16, no. 4. P. 34-43. https://doi.org/10.15407/scine16.04.034 
all warm-blooded animals, a characteristic feature of the human body, is to maintain a constant body temperature regardless of ambient temperature. The set of physiological processes that maintain body temperature at a constant level by means of the central nervous system is called thermoregulation [2]. Hence, the human body is a self-regulating system in which the amount of heat production is equal to the amount of heat transfer to the environment.

The main purpose of blankets at home is to protect the human body from effects of uncomfortable low temperature. It is the blanket that creates an artificially regulated microclimate for a person, which, reducing body heat loss, provides favorable conditions for maintaining a constant body temperature. As a barrier that protects the human body from lower ambient temperature, the blanket maintains the heat balance of the human body and prevents an excessive heat loss.

Recently, there has been a global trend towards widespread use of textile products from natural raw materials that are environmentally friendly and safe for the consumers. To optimize the range and design of blankets with the specified properties, the most important is to choose a filler, in terms of its thermophysical parameters. A significant share in the world market belongs to blankets with wool fillers [3, 4]. However, the thermophysical parameters of various types of wool (sheep, camel, cashmere) differ from each other.

There are researches dealing with the thermophysical properties of materials with various structures for the manufacture of consumer goods. The researchers pay considerable attention to the development of methods for assessing and measuring thermophysical parameters of nonwoven textile materials used as insulation for finished clothing $[5,6]$, developing methods and studying the effects of porosity, moisture, and pressure on thermal conductivity of fabrics [7, 8], and calculating uncertainty of properties of knitted fabrics [9, $10]$ and thermal conductivity of needle-punched nonwoven textile materials from heat-resistant fibers [11]. Many researchers have used a modern mathematical apparatus to model the temperature of the human body under external temperature influences [12] and simulated heat transfer through textile material [13]. Many studies deal with the improvement of methods and means of control of physical parameters, in particular, for textile materials [14, 15].

Studies of thermophysical phenomena for leather and polymer materials through the assessment of thermal destruction allow establishing structural transformations and predicting the functional properties of finished products [1618], which may be useful for studying the properties of textile fillers.

Particular attention should be paid to studying thermal resistance and thermal design of quilted blankets [1], as well as deformation, volume of fibers of pillow fillers, and quilted blankets under the action of pressure with estimation of heat retention properties [19]. There are many publications dealing with the study of heat retention properties of blankets estimated based on the total thermal resistance [20-22].

In addition, the heat conductivity of blankets with natural fillers of animal origin (sheep, camel, cashmere) have been understudied.

The purpose of this research is to estimate the heat conductivity of textile fillers from different types of wool. In the future, monitoring and measuring these characteristics will enable optimizing the choice of materials when designing bed clothing with bulky fillers, including blankets.

The object of the study is sample of fillers of different fibrous composition (sheep, camel, cashmere wool and polyester fiber). Thermophysical characteristics (TFC) of these samples have been determined for comparative analysis. The prototypes have been manufactured at the facilities of Gerd Billerbeck GmbH (Kyiv, Ukraine).

Since the temperature conditions of the space between the human body and the blanket are provided by heat retention properties of the latter, below there is a classification of the properties of blanket as an element of communication with the environment (Fig. 1). 


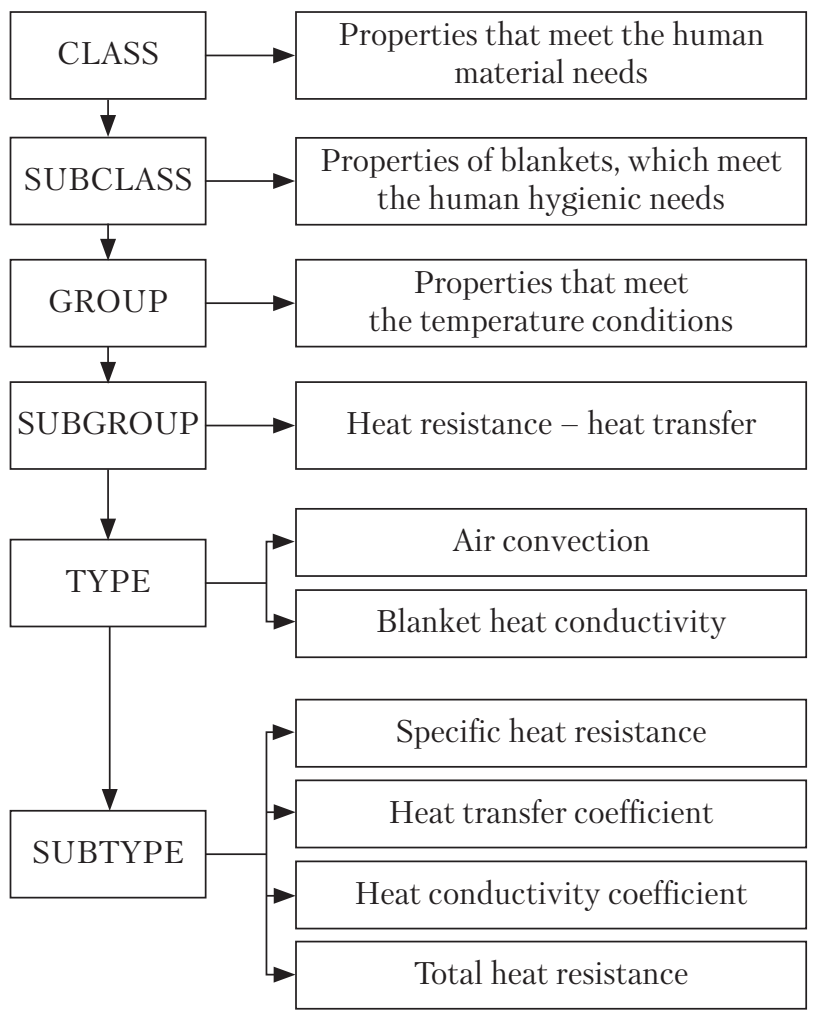

Fig. 1. Classification of blanket properties

For detailed classification of heat retention properties of bed clothing with bulky fillers, in particular, blankets, it is advisable to present this classification in the form of a hierarchical subset system. This system is built taking into account the natural connections, scientific principles, and rules of taxonomy.

It is known that different taxonomic categories: class, group, species, etc., are used to denote subsets or levels of classification, with objects referred to one or another category according to certain features.
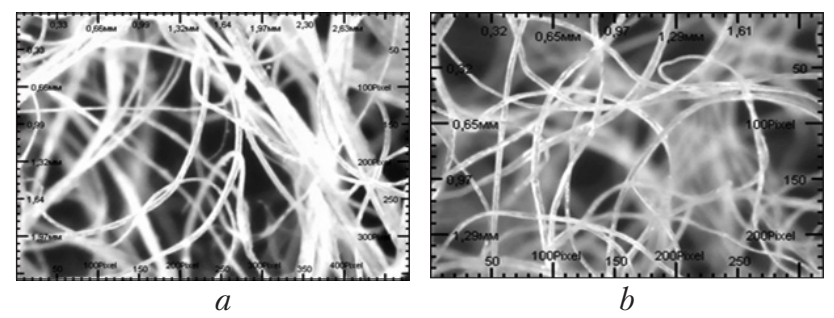

Thermophysical characteristics are important for blankets, since the fillers of different fibrous composition are characterized by different physical properties and differ not only in the structure of the natural material (wool), but also in the amount of air between its fibers. The amount of air affects the material heat transfer and its thermal resistance in general.

Surface density, air permeability and relative total thermal resistance of blanket fillers have been determined at the Laboratory for Analytical Research and Testing of Products of the R\&D Center for Conformity, Standardization and Testing of Light Industry Products and Personal Protective Equipment of Ukrmetrteststandart (Kyiv, Ukraine). Photographs of the fillers have been made at the laboratory of the Kyiv National University for Trade and Economics (Kyiv, Ukraine) by the photometric method, using microscopes MPB-2, MG 10085-1A with a resolution of 600 pixels and Micro-Measure software. The microscopic studies of textile filler samples for blankets are illustrated in Fig. 2.

The length of textile fibers varies from 20 to $150 \mathrm{~mm}$. Natural fibers have a limited length, for example, 6-51 mm (cotton), 250-1000 mm (linen), 10-250 mm (wool), 400-1000 mm (natural silk) [23]. As for synthetic fibers, they can have unlimited length and are produced in the form of textile threads or in the form of staples or $40-150 \mathrm{~mm}$ long thrums [20].

The thickness of fibers has been determined by the microscopic survey. Thus, cashmere wool fibers have a thickness of $0.0333 \pm 0.00202 \mathrm{~mm}$, sheep wool fibers are $0.0506 \pm 0.00380 \mathrm{~mm}$ thick, camel wool fibers are $0.0178 \pm 0.00212 \mathrm{~mm}$ thick,
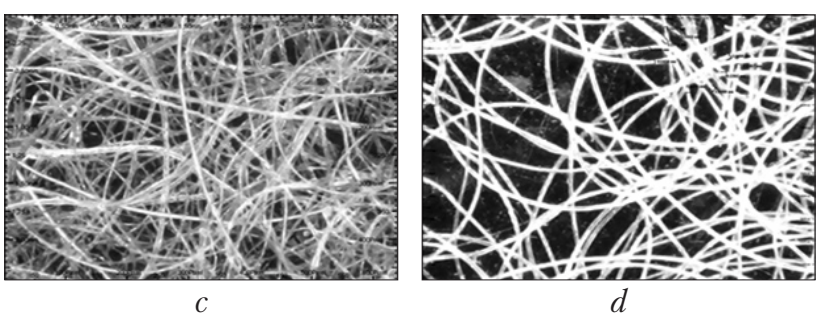

Fig. 2. Structure of blanket fille, $\times 600: a$ - sheep wool; $b$ - cashmere wool; $c$ - camel wool; $d$ - polyester fiber 
polyester fiber has a thickness of $0.0372 \pm 0.0015$ $\mathrm{mm}$. Depending on the origin, difference in wool fiber size ranges from 2 to $11 \%$, while for polyester fibers it varies from 1 to $4 \%$.

The microscopic analysis has shown that the camel wool fillers are characterized by dense fiber packaging. The samples of blankets contain fibers of different sizes, with small and large gaps between them filled with air. The samples of sheep wool (Fig. 2, $a$ ), cashmere (Fig. 2, $b$ ), and polyester fiber (Fig. 2, $d$ ) are characterized by almost identical size of fibers. These fillers have different densities and, accordingly, different masses of air contained in them. Air plays a key role in the heat conductivity and heat capacity of the test samples. Air is known to be a poor conductor of heat, however, if the mobility of the air mass is high enough, its heat transfer is significant. Filler fibers also have a different nature of heat transfer, which depends on the molecular structure of the fiber, or rather, on its molecular bonds. After all, heat, as a measure of the average kinetic energy of molecules, characterizes the oscillatory processes of molecular system. In addition, the rate of heat transfer is affected by the humidity of air layer, which is variable and depends on the physiological state of man, his physical activity, humidity of environment, and on other factors.

Determining the thermophysical characteristics of raw materials is a rather complicated and time-consuming process. Therefore, the urgent task is to develop new or to improve existing methods using computer technology that enable automating the process of research while maintaining the integrity of the studied objects, enhancing the accuracy and efficiency of experimental data processing. Such devices include a multifunctional modular measuring device (BFMVP) MIG-1.3, using which the experimental studies of heat conductivity of textile fillers for blankets have been conducted. The research has been performed in the laboratories of the Kyiv National University for Trade and Economics by the heating (cooling) method, with the use of the Heat module of MIG-1.3 device [24] (Fig. 3). The time interval

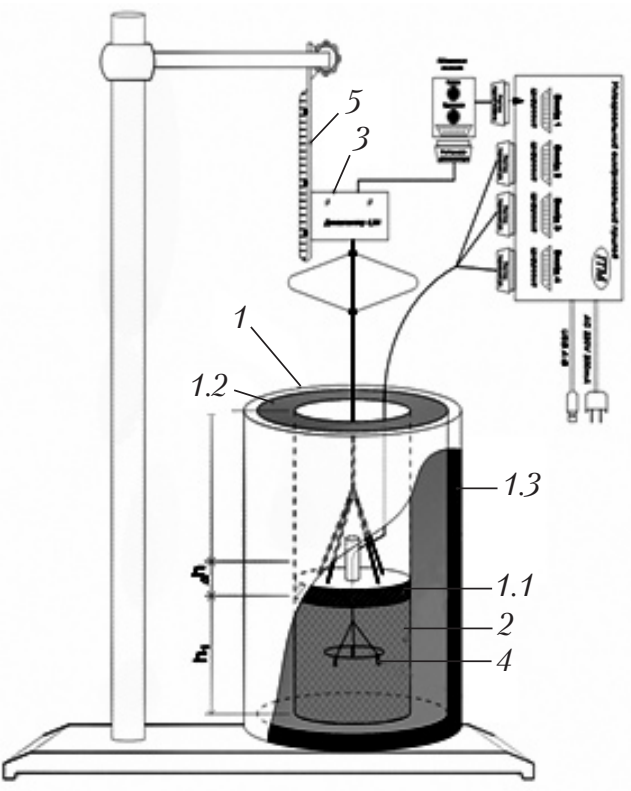

Fig. 3. Section scheme of the Heat module: 1 - thick-walled cylinder; 1.1 - movable piston; 1.2 - insulationa; 1.3 - the outer cylinder (made of plastic); 2 - test sample; 3 - dynamometer; 4 - system of temperature sensors; 5 - measuring scale of the module filling

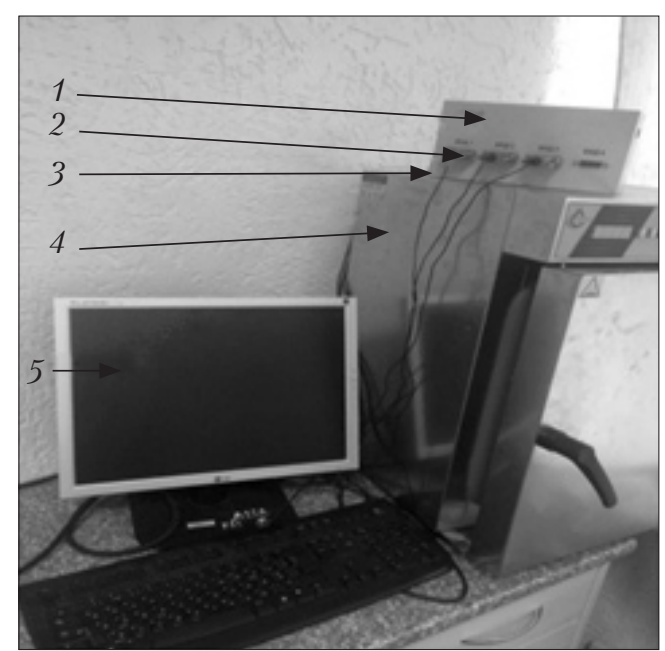

Fig. 4. Appearance of BFVMP MIG-1.3: 1 - control unit of the sensor system of Heat module; 2 - temperature sensors (connected to inputs 1, 2, 3, 4); 3 - sensor for temperature and humidity control in the working chamber; 4 - heating cabinet with temperature control sensors and modes of heating of the cabinet; 5 - computer display showing graphical dependences of temperature fluctuations in the working chamber and samples 


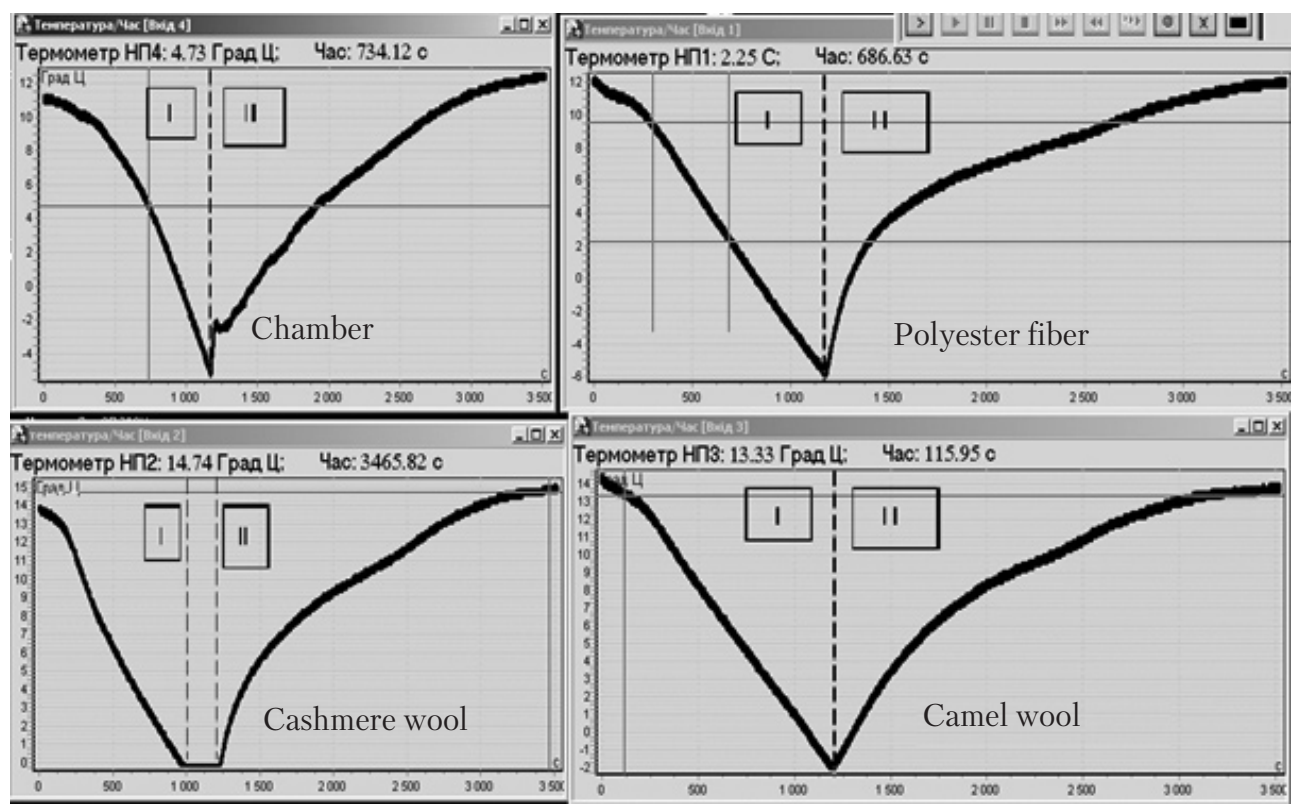

Fig. 5. Temperature fluctuation in the area of cooling $(I)$ and heating $(I I)$ : ): input 1 - polyester fiber; input 2 - cashmere; input 3 - camel wool; input 4 - chamber

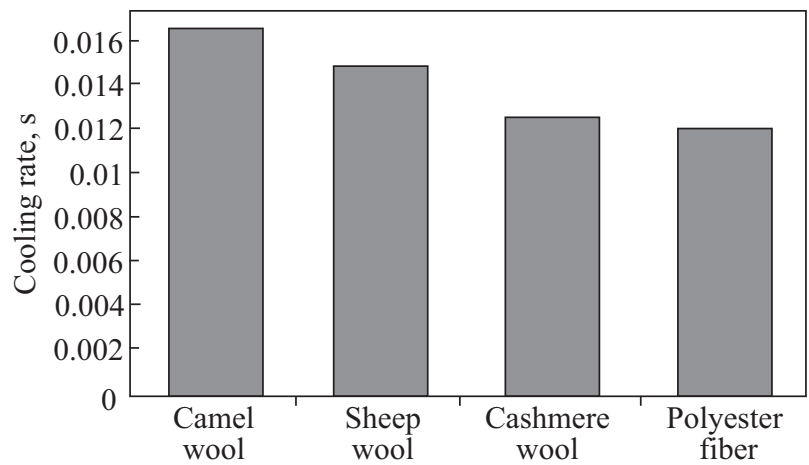

Fig. 6. Ranking of studied fillers by cooling rate

for recording indicators is $0.01 \mathrm{~s}$, the temperature is $0.01{ }^{\circ} \mathrm{C}$, the straining force ranges from $5 \mathrm{mN}$ to $5 \mathrm{~N}$ (determined if necessary for experiment). The obtained experimental data is displayed on the screen of a personal computer in real time, where while studying, one can take a picture of the screen. The resulting data set is accumulated in files exported to MS Excel (Fig. 4).

The Heat module of the MIG-1.3 device can be used to study various structural materials [24]. The design of the module provides for the connection of a heating (cooling) element in the lower part of the module, where its bottom has removable insulation. To determine the thermophysical characteristics of blanket fillers, the method of two temperature-time intervals has been used [25]. The system of sensors of the Heat module in real time within one experiment takes readings of temperature fluctuations in the heater chamber $M 1$ and the heat receiver $B$ on the principle of a buffer zone.

To determine the thermophysical characteristics of blanket fillers, a series of experimental studies of fluctuations in the cooling (heating) temperature of blankets with natural and synthetic textile fillers has been conducted (Fig. 5).

As one can see, all the samples in the working chamber at the same time start cooling down. In this case, they have the same specific mass $(\mathrm{m} / \mathrm{V})$ and different initial temperatures. In the chamber, as the temperature decreases, the thermal equilibrium between the chamber and the sample is disturbed and heat is transferred to the samples with a temperature gradient directed towards the sample of textile filler. According to calculations, to reduce the temperature in the chamber to $0{ }^{\circ} \mathrm{C}$, 
it is necessary to remove $258 \mathrm{~kJ}$ heat from the system; based on the diagram, this process lasts 1000 seconds.

To optimize the choice of the studied textile fillers, an appropriate histogram of their cooling rate has been built (Fig. 6).

The rate of cooling down to a temperature of $0{ }^{\circ} \mathrm{C}$ for each textile filler is different. The lower the cooling rate, the longer the textile filler keeps heat inside, the slower it cools down, the slower it heats up. The smoothness of this process provides comfort for the human body covered with a blanket. According to the results of the study, the best filler for the blanket is camel wool, the second one is sheep wool, and the third ones are cashmere wool and synthetic fiber. Mathematically, this process is described by the following equations: where $T$ is the temperature, ${ }^{\circ} \mathrm{C}$; $t$ is time, s (Table 1).

As can be seen from the equations, the change in temperature over time is described by secondorder equations, i.e. the nature of the thermal field penetration into the samples, as well as their thermophysical characteristics, shall be close to each other.

From the point of view of thermophysics and the zero principle of thermodynamics, heat is transferred from a hotter body to a less heated one. For blankets with different fillers, one of the main thermophysical properties is thermal conductivity a that characterizes the rate of thermal field change in the sample and depends on heat conductivity $\chi$, specific heat storage capacity $c$ and bulk density $m$ of the material, and determines the rate and uniformity of heating materials [6].

The thermal conductivity coefficient $a$ for fillers has been determined by the method of two temperature-time intervals. The essence of the

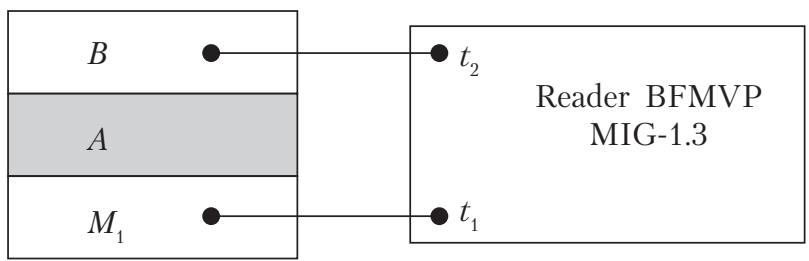

Fig. 7. Flowchart of recording two temperature-time intervals: $M_{1}$ - heater; $A$ - sample; $B$ - heat sink; $t_{1}$ - thermal sensor $1 ; t_{2}$ - thermal sensor 2 of the Heat module

method is that the heat released by the heater $M 1$ (Fig. 7) is absorbed by the textile material $A$ and transferred to the heat $\operatorname{sink} B$. The thermophysical characteristics of materials is determined by the heating or cooling rate. The temperaturetime curves in the Heat module are recorded by four temperature sensors. If necessary, it is possible to record changes in temperature in each layer of the test sample. In the method, the test sample plays the role of a buffer zone, so two connected temperature sensors are enough for the study.

According to the method of two temperature-time intervals, the thermal conductivity coefficient is calculated by the formula:

$$
a=\frac{h^{2}}{4 y^{2} \tau},
$$

where $h$ is the thickness of the sample, m; $y$ is the temperature range, ${ }^{\circ} \mathrm{C}$; $\tau$ is time interval, $\mathrm{s}$.

The time and temperature intervals are determined from the obtained temperature-time curves graphically, as shown in Fig. 8.

To do this, it is necessary to draw an isothermal line, that is a line of equal temperature (for example, $15^{\circ} \mathrm{C}$ ) in the curves $A 1$ and $A 2$ with respect to the curve $M 1$. At the intersection with the curves we obtain points at which we determine the time interval of temperature variation to the specified values. According to the graphical data, the cooling/ heating rate of the blanket fillers is calculated.

Table 1. Mathematical Equation of Temperature Fluctuation's

\begin{tabular}{|l|c|c|}
\hline \multicolumn{1}{|c|}{ Filler } & Equation & Correlation factor \\
\hline Camel wool & $T=-4 \times 10^{-6} t^{2}-0.0055 t+21.558$ & $R^{2}=0.9947$ \\
Sheep wool & $T=-1 \times 10^{-6} t^{2}-0.0137 t+22.626$ & $R^{2}=0.9946$ \\
Cashmere wool & $T=-0.7 \times 10^{-6} t^{2}-0.0151 t+19.135$ & $R^{2}=0.9985$ \\
Polyester fiber & $T=-2.2 \times 10^{-6} t^{2}-0.751 t+13.254$ & $R^{2}=0.9874$ \\
\hline
\end{tabular}




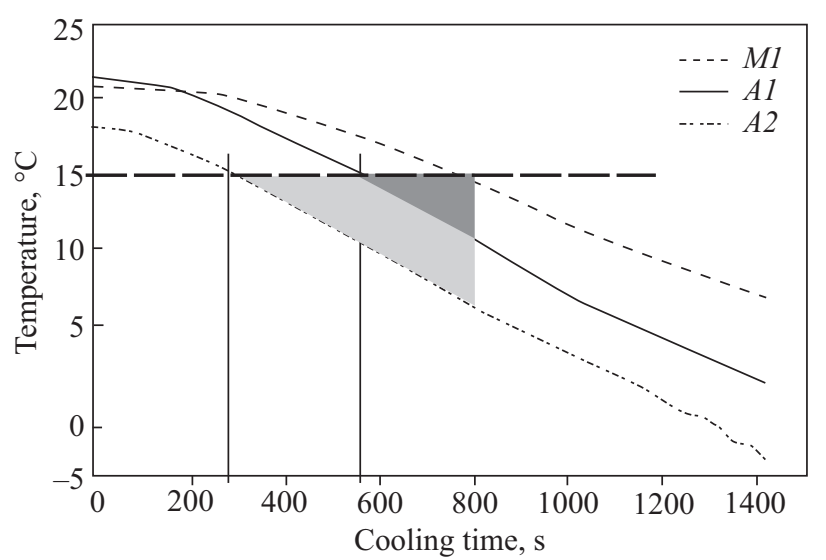

Fig. 8. Temperature-time intervals for determining the thermal conductivity coefficients of fillers: $M_{1}-$ heater; $A_{1}-$ polyester fiber; $A_{2}$ - camel wool

The obtained values of the thermal conductivity coefficient for blankets with different textile fillers are given in Table 2.

The next stage of research is to establish a variation of the specific heat storage capacity of the material depending on temperature, because heat storage capacity is one of the main thermophysical properties of the material, which indicates how much energy (heat) is necessary to supply to the material having a mass of $1 \mathrm{~kg}$ to change its temperature by $1{ }^{\circ} \mathrm{C}$.

The specific heat storage capacity is determined from the heat balance equation. The amount of heat coming from the heater is completely transferred to the test sample (thanks to the design of MIG-1.3). Amount of heat issued by the heater is calculated by the Joule-Lenz law IU $t$, this energy heats a textile filler $\left(c m \Delta t^{\prime}\right)$; on the other hand, the heating process depends on thermophysical properties of samples, which are des- cribed by the Fourier law $\left(\lambda / \mathrm{s}\left(t_{\mathrm{cr} 1}-t_{\mathrm{cr} 2}\right)\right.$, i.e. we get the following equation:

$$
I U \Delta t=c m \Delta t^{\prime}=\lambda / \mathrm{s}\left(t_{\mathrm{cr} 1}-t_{\text {ст2 }}\right),
$$

where $I$ is current, A; $U$ is voltage, $\mathrm{B}$; $\Delta t$ is duration of heater operation, $\mathrm{s} ; c$ is specific heat storage capacity of material, $\mathrm{J} / \mathrm{kg} \cdot{ }^{\circ} \mathrm{C}$; $m$ is mass of the sample, $\mathrm{kg} ; \Delta t^{\prime}=\left(t_{\mathrm{cr} 1}-t_{\mathrm{cr} 2}\right)$ is change in the sample temperature, ${ }^{\circ} \mathrm{C} ; t_{\mathrm{cr} 1}$ is temperature at the heater-sample interface $\left(M_{1} A\right),{ }^{\circ} \mathrm{C}$; $t_{\text {cr1 }}$ is temperature at the sample-heat sink interface $(A B),{ }^{\circ} \mathrm{C}$.

According to the published data [26], the specific heat storage capacity of pure sheep wool and cashmere varies within $2600 \pm 352 \mathrm{~J} /\left(\mathrm{kg} \cdot{ }^{\circ} \mathrm{C}\right)$. The experiments with the mentioned samples have established the functional dependence of changing the specific heat storage capacity on temperature:

$$
\begin{gathered}
c_{\text {sheep }}=-68.775 t+3478.1, R^{2}=0.94, \\
c_{\text {cashmere }}=-96.54 t+3583.5, R^{2}=0.95 .
\end{gathered}
$$

The obtained dependences are linear. At low temperatures (below $0{ }^{\circ} \mathrm{C}$ ), heat capacity increases, however, as temperature increases, heat capacity decreases. For example, at $0{ }^{\circ} \mathrm{C}$, the sheep wool filler heat capacity is $3478.1 \mathrm{~J} /\left(\mathrm{kg} \cdot{ }^{\circ} \mathrm{C}\right)$, while that of cashmere wool is $3583.5 \mathrm{~J} /\left(\mathrm{kg} \cdot{ }^{\circ} \mathrm{C}\right)$. As temperature increases to $20^{\circ} \mathrm{C}$, the heat capacity of the fillers is 3340.6 and $3390.4 \mathrm{~J} /\left(\mathrm{kg} \cdot{ }^{\circ} \mathrm{C}\right)$, respectively. The obtained values of heat capacity for fillers are used to calculate their heat conductivity coefficients. The specific heat capacity of fillers and its dependence on ambient temperature is an important factor for calculating the geometric parameters of blankets, the thickness of the filler, its thermal resistance, air and water permeability.

Table 2. Calculated Thermal Conductivity Coefficient for Blanket Textile Fillers

\begin{tabular}{|l|c|c|c|c|}
\hline \multicolumn{1}{|c|}{ Filler } & $\begin{array}{c}\text { Thermal } \\
\text { conductivity coefficient, } \\
a, \cdot 10^{-8} \mathrm{~m}^{2} / \mathrm{s}\end{array}$ & $\begin{array}{c}\text { Surface density, } \\
\mathrm{g} / \mathrm{m}^{2}\end{array}$ & $\begin{array}{c}\text { Air permeability, } \\
\mathrm{dm}^{3} / \mathrm{m}^{2} \mathrm{~s}\end{array}$ & $\begin{array}{c}\text { Total relative heat } \\
\text { resistance, } \\
\mathrm{m}^{2}{ }^{\circ} \mathrm{C} / \mathrm{W}\end{array}$ \\
\hline Camel wool & $3.535 \pm 0.287$ & 540 & 27.7 & 0.327 \\
Sheep wool & $3.828 \pm 0.122$ & 477 & 28.7 & 0.321 \\
Cashmere wool & $4.105 \pm 0.305$ & 527 & 27.5 & 0.292 \\
Polyester fiber & $7.031 \pm 0.036$ & 536 & 31.7 & 0.278 \\
\hline
\end{tabular}


Having experimental data of temperature variation in the chamber and in the sample, one can calculate the heat conductivity coefficient of material. It is an important thermophysical property of textile material. The heat conductivity values have been compared with the tabular data given in various literature sources [27, 28].

It should be noted that these data are given for textile fibers or for woven fabrics. The heat conductivity ranges within $0.033-0.040 \mathrm{~W} /\left(\mathrm{m} \cdot{ }^{\circ} \mathrm{C}\right)$ for textile materials and $0.020 \mathrm{~W} /\left(\mathrm{m} \cdot{ }^{\circ} \mathrm{C}\right)$ for air. The heat conductivity coefficients for different types of blanket fillers are given in Table 3.

The blanket with a bulky filler is an inhomogeneous material, a system of a large number of fibers separated from each other by pores of different shapes and sizes, filled with air. That is why the experimentally measured heat conductivity is slightly higher than the tabular data.

With the help of mathematical simulation, it is expedient to design the necessary properties of textile fillers of blankets, namely, to choose the thickness and the composition of the filler for the required temperature conditions. For example, the dependence of heat conductivity of sheep wool filler on temperature while cooling (with a high coefficient of reliability) is shown in Fig. 9. As one can be seen from the figure, at a temperature of $11-13{ }^{\circ} \mathrm{C}$, heat conductivity is stabilized and the change is insignificant. Thus, the cooling and, accordingly, the heating of sample occurs smoothly, the person feels more comfortable than in the case where the filler is a polyester textile fiber (Fig. 10).

The irregular shape of curve and the abrupt reproduction of the change in the heat conductivity indicate the unstable thermophysical properties

Table 3. Heat Conductivity of Textile Fillers for Blankets

\begin{tabular}{|l|c|c|}
\hline \multicolumn{1}{|c|}{ Filler } & $\begin{array}{c}\text { Heat conductivity } \\
\text { coefficient, } \\
\lambda, \mathrm{W} /\left(\mathrm{m}{ }^{\circ} \mathrm{C}\right) \\
(\text { experiment) }\end{array}$ & $\begin{array}{c}\text { Heat conductivity } \\
\text { coefficient, } \\
\lambda, \mathrm{W} /\left(\mathrm{m} \cdot{ }^{\circ} \mathrm{C}\right) \\
\text { (tabular) }\end{array}$ \\
\hline Camel wool & 0.04140 & - \\
Sheep wool & 0.05708 & $0.03-0.05$ \\
Cashmere wool & 0.08640 & - \\
Polyester fiber & 0.09130 & 0.05 \\
\hline
\end{tabular}

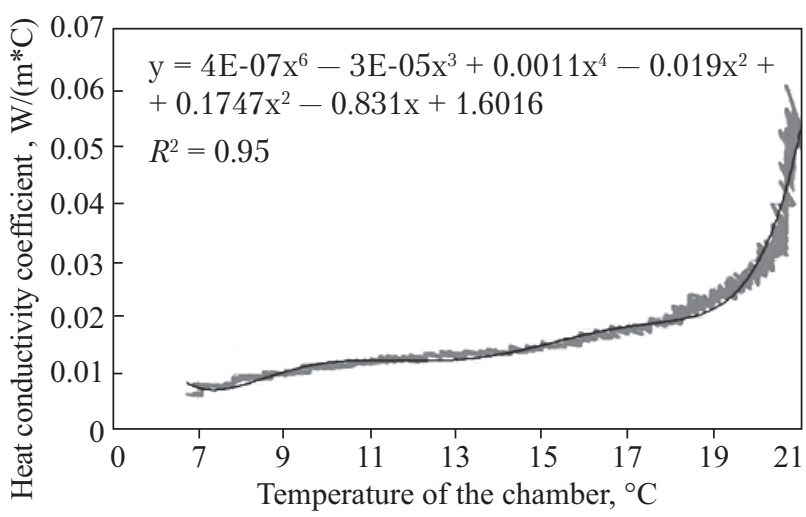

Fig. 9. Dependence of heat conductivity coefficient of sheep wool on temperature fluctuations while cooling down

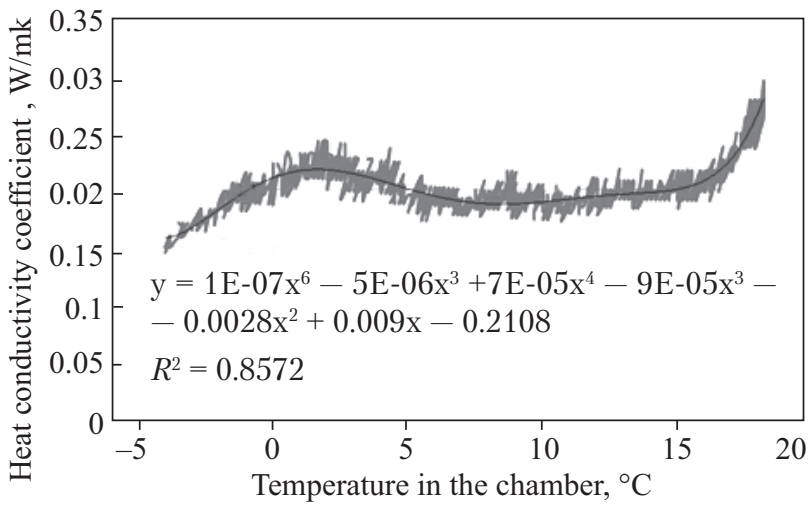

Fig. 10. Dependence of heat conductivity coefficient of polyester fiber on temperature fluctuations while cooling down

of the thermal field, its heterogeneity, and the fact that it has a moment of accumulation of thermal energy in the middle of the filler and a very complicated nature of heat conductivity. The accumulation of additional heat energy and moisture in the sample leads to discomfort.

The figures show that as the temperature decreases, the heat conductivity of wool is $0.116 \mathrm{~W} /$ $\left(\mathrm{m} \cdot{ }^{\circ} \mathrm{C}\right)$, while at a temperature of $20^{\circ} \mathrm{C}$ it is equal to $0.0375 \mathrm{~W} /\left(\mathrm{m} \cdot{ }^{\circ} \mathrm{C}\right)$. For polyester fiber, at a low temperature, the heat conductivity is $0.150 \mathrm{~W} /$ $\left(\mathrm{m} \cdot{ }^{\circ} \mathrm{C}\right)$, while at a temperature of $20^{\circ} \mathrm{C}$, it is equal to $0.278 \mathrm{~W} /\left(\mathrm{m} \cdot{ }^{\circ} \mathrm{C}\right)$.

Surely, the heat conductivity of textile filler is one of the main functional properties of blankets that are designed to protect the human body from the environment. 
Hence, in the future, monitoring and measurement of heat conductivity of textile fillers enable optimizing their choice while designing bed clothing with bulky fillers, including blankets.

The estimates of heat conductivity of textile fillers used for the manufacture of blankets have made it possible to assume, with a high degree of reliability, as follows.

1. In the case of a relatively calm air with a low relative humidity, the crucial factor for the heat conductivity of natural and synthetic textile fillers for blankets is the fibrous composition, the microstructure of the textile filler, and the nature of air retention.
2. Given the experimental data, it is possible to rank natural and chemical textile fillers by heat conductivity, in the descending order: camel wool $\rightarrow$ sheep wool $\rightarrow$ cashmere wool $\rightarrow$ polyester fiber.

3. Among the natural textile fillers, camel wool fiber has the least heat conductivity of $0.04140 \mathrm{kcal} /$ $\mathrm{m} \cdot \mathrm{h}$ degree.

The obtained heat conductivity data of natural protein fibers shall be taken into consideration when designing the heat retention properties of bed clothing with bulky fillers, in particular blankets, to optimize the range of products and to meet the needs of consumers.

\section{REFERENCES}

1. Razbrodyn, A. V. (2006). Study of thermal resistance and thermal calculation of quilts with various fillers. (Doctoral dissertation). Moscow [in Russian].

2. Skliannykov, V. P. (1982). Consumer properties of textile goods. Moscow: Economy. [in Russian].

3. Galko, S., Mihaylova, G., Osievska, V. (2017). World goods market: blankets and plaids. Light industry, 1, 45-47 [in Ukrainian].

4. Galko, S., Mihaylova, G., Osievska, V. (2017). World market of blankets and plaids. Goods and markets, 1, 5-15 [in Ukrainian]

5. Boeva-Kashlova, H. (2009). Study of the thermophysical characteristics of two-component nonwoven materials. Goods and markets, 1, 104-109 [in Russian].

6. Sokolovskaia, T. S. (2008). Development of methods for assessing and measuring the thermophysical parameters of nonwoven textile materials. (PhD.) (Tech.). Moscow [in Russian].

7. Sukhodolskyi, M. A., Ysaev, V. V. (2007). Study of the effect of porosity on the thermal conductivity of tissues. Textile industry, 4, 43-47 [in Russian].

8. Bessonova, N. H. (2005 Development of methods and study of the thermophysical properties of textile materials and bags under the action of moisture and pressure. (PhD.) (Tech.). Moscow [in Russian].

9. Kolesnykov, N. V., Davidov, A. F. (2011). Study of the heat-shielding properties of functional knitted fabrics for linen. Textile industry, 3, 32-33 [in Russian].

10. Abdukaiumov, A. A., Dzhabbarov, R. R., Khakymov, O. Sh. (2012). Uncertainty of the method for measuring the thermal conductivity of wet knitted fabrics. Information Processing Systems, 1, 97-99 [in Ukrainian].

11. Murashova, V. E., Kurochkyn, Y. A., Voloshchyk, T. E. (2007). The study of thermal conductivity of needle-punched nonwoven materials made of heat-resistant fibers. Technology of the textile industry, 3(298), 85-87 [in Russian].

12. Stasevych, S., Kazymyra, I., Plavaika, M. (2018). Modeling of the human body under external temperature influences. Proceedings of the International Scientific Symposium SVED'2018 "Sustainable Development - Status and Prospects" (February 28-March 3, 2018, Lviv. Slavske), 163-164 [in Ukrainian].

13. Halavska, L. Ye. (2012). Mathematical modeling of heat transfer through textile material. Bulletin of KNUTD, 1, 105109 [in Ukrainian].

14. Yanenko, O. P., Vahanov, O. A. (2009). Methods and means of control of physical parameters of textile materials. Bulletin of NTUU „KPI“, 38, 107-111 [in Ukrainian].

15. Mokrousova, E., Dzyazko, Y., Volfkovich, Y., Nikolskaya, N. (2016). Hierarchical structure of the derma affected by chemical treatment and filling with bentonite: Diagnostics with a method of standard contact porosimetry. Nanophysics, Nanophotonics, Surface Studies, and Applications. Springer Proceedings in Physics, 183, 277-290.

16. Kovtunenko, O., Travinskaya, T., Mokrousova, O. (2016). Thermal properties of anionic polyurethane composition for leather finishing. Material science, 22 (3), 394-399.

17. Palamar ,V. A., Mokrousova, O. R., Okhmat, O. A. (2016). Heat-resistant properties of leather obtained using modified montmorillonite. Bulletin of Khmelnytsky National University. Technical sciences, 3, 237-244 [in Ukrainian]. 
18. Maruhlenko, M. O., Palamar, V. A., Mokrousova, O. R. (2016). Stabilizing derma collagen structure with modified dispersions of montmorillonite. IOP Conference Series: Materials Science and Engineering, 111(1), 1-8.

19. Yudyn, B. V. (2009). Investigation of deformations, volume during compression of filler fibers of pillows, quilted blankets with an assessment of their heat-shielding properties. (PhD.) (Tech.). Moscow [in Russian].

20. Mykhailova, H. M., Forostiana, N. P. (2016). Thermal properties of blankets with bulk fillers. Goods and markets, 1(21), 96-105 [in Ukrainian].

21. Mykhailova, H. M., Osiievska, V. V., Halko, S. V. (2016). Thermal properties of blankets with cellulose textile fillers. Proceedings of the IV International Scientific and Practical Conference "Innovations in the management of the range, quality and safety of goods and services." (November, 24, 2016, Lviv), 179-181. Lviv [in Ukrainian].

22. Mykhailova, G., Osiievska, V., Bulenok, S. (2016, September). Thermalphysic Characteristics of Bedding Products are a Source of a Person's Sound Sleep. 20 I IGWT Symposium «Commoditi Science in a Chientific Works» (September 12-16, 2016, Varna. Bulgaria), 702-708. Varna.

23. Puhachevskyi, H. F., Semak, B. D. (1999). Commodity science of non-food products. Part 1. Textile commodity science. Kyiv: NMTs «Ukoopspilka [in Ukrainian].

24. Shapoval, S. L., Romanenko, R. P., Forostiana, N. P. (2017). Diagnosis of physical properties of food products: monograph. Kyiv [in Ukrainian].

25. Volkenshtein, V. S. (1971). Rapid method of determination of the thermophysical properties of materials. Leningrad [in Russian].

26. Kiryuchin, S. M., Shustov, Yu. S. (2011). Textile Materials Science. Moscow [in Russian].

27. Kolesnikov, P. A. (1965). Thermal protective properties of clothes. Moscow [in Russian].

28. Miroshnikov, E. A. (1974). Thermal properties of materials and products. Kyiv [in Ukrainian].

Received 23.01.19

Revised 17.02.19

Accepted 15.05.19

\section{Н.П. Форостяна, Г.М. Михайлова, В.В. Осієвська, Н.Б. Марчук}

Київський національний торговельно-економічний університет, вул. Кіото, 19, Київ, 02156, Україна,

+38044513 8172, ktms@knute.edu.ua

\section{ОЦІНКА ТЕПЛОПРОВІДНОСТІ ВОВНЯНИХ} ТЕКСТИЛЬНИХ НАПОВНЮВАЧІВ ДЛЯ КОВДР

Вступ. Для оптимізації асортименту та конструювання ковдр із заданими властивостями суттєву роль відіграє вибір наповнювача, зокрема його теплофізичні показники, які у різних матеріалів різняться між собою.

Проблематика. Теплопровідність ковдр з наповнювачами протеїнового походження, зокрема вовни овечої, верблюжої, кашемірової, практично не вивчена. Контроль та вимірювання зазначеного показника дозволить в перспективі оптимізувати вибір матеріалу під час проєктування постільних виробів з об’ємними наповнювачами, зокрема ковдр.

Мета. Оцінка теплопровідності текстильних виробів з різними типами наповнювачів.

Матеріали й методи. Об’єктом дослідження слугували зразки наповнювачів різного волокнистого складу - овечої, верблюжої, кашемірової вовни. Експериментальні дослідження було проведено в лабораторіях Київського національного торговельно-економічного університету з використанням модуля «Тепллота» багатофункціонального вимірювального модульного пристрою «MIG-1.3». Фотографії наповнювачів зроблено на універсальному вимірювальному комп’ютерному приладі із роздільною здатністю 600 пікселів.

Результати. Мікроскопічні дослідження волокон показали, що щільність наповнювачів є різною, а отже й маса повітря в них та, відповідно, маса самих волокон наповнювачів різниться між собою, що в результаті впливає на теплопровідність матеріалу. За отриманими даними сформовано ряд наповнювачів за зменшенням їхньої теплопровідністі: вовна верблюжа $\rightarrow$ вовна овеча $\rightarrow$ вовна кашемірова $\rightarrow$ поліефірне волокно.

Висновки. Отримані результати показали, що найбільш ефективним щодо теплозбереження $є$ напов $\neg$ нвач 3 верблюжої вовни, тоді як поліефірне волокно має показник теплопровідності у 2,2 рази нижчий, що варто враховувати при формуванні теплозахисних властивостей постільних виробів з об'ємними наповнювачами, зокрема ковдр, 3 метою оптимізації асортименту останніх.

Ключові слова: ковдра, вовна овеча, вовна верблюжа, вовна кашемірова, волокно поліефірне, теплопровідність. 